\title{
Diverse Responses of Membrane-associated Enzymes of Ehrlich Ascites Tumor Cells to Anti-microtubular Agents
}

\author{
Tomonori Kurokawa, Misuzu Seo and Sadahiko Ishibashi \\ Department of Physiological Chemistry, Hiroshima University School of Medicine, \\ Hiroshima 734, Japan
}

\begin{abstract}
Ehrlich ascites tumor-bearing mice were treated with colchicine or mitomycin C. Under colchicine, adenylate cyclase activity in tumor cells decreased to about a third of the untreated control level, whereas 5'-nucleotidase activity increased to almost twice the control level. Colchicine treatment resulted in about a $30 \%$ reduction of ${ }^{3} \mathrm{H}$-thymidine incorporation into DNA. Mitomycin $\mathrm{C}$ inhibited the incorporation of ${ }^{3} \mathrm{H}$-thymidine much more markedly but changes in the two enzyme activities were less than under colchicine. The two enzyme activities and ${ }^{3} \mathrm{H}$-thymidine incorporation into DNA showed parallel changes with lapse of time after inoculation of tumor cells into mice. Thus, the colchicine effects on the two enzyme activities seemed not due simply to inhibition of cell proliferation. The two enzymes seemed to be associated differently with the microtubular system in Ehrlich ascites tumor cells.
\end{abstract}

Various intracellular events induce changes in the composition and property of the cell surface, which in turn, affect the functions of the cell. It was indicated by Yahara and Edelman (12) that plasma membrane-associated events, e.g., lateral diffusion, seemed to be mediated by the microtubular system. On the other hand, Chen, Heller and Canellakis (6) reported that colchicine and vinblastine inhibited the activity of ornithine decarboxylase, a cytoplasmic enzyme, in cultured L1210 cells, while Bos and Emmelot (3) found that vinblastine inhibited the activity of glucagon-stimulated adenylate cyclase in the isolated plasma membrane of liver. These findings seem to indicate that the microtubular system is involved in the functioning of the plasma membrane, as well as that of the cytoplasm, and in the interaction between them. Thus, we were interested in clarifying the relationship between the membrane-associated enzymes and the microtubular system.

In the present study, the activities of adenylate cyclase and 5'-nucleotidase, both plasma membrane-associated enzymes $(1,9)$ were examined in Ehrlich ascites tumor cells. Treatment of tumor-bearing mice with colchicine caused diverse changes in the activity of the two enzymes, whereas the two enzyme activity responses were almost parallel under other conditions. These results suggested the existence of a peculiar regulatory system connected with microtubules, for each of the cell membraneassociated enzymes.

Colchicine, $\mathrm{NaF}$, and alumina (neutral, activated grade I) were purchased from $\mathrm{E}$. Merck A.G. (Darmstadt, West Germany); mitomycin C from Kyowa Hakko Co. (Tokyo, Japan); ATP, AMP, cyclic AMP, creatine kinase, phosphocreatine, and dithiothreitol from Sigma Chemical Co. (St. Louis, Mo.); $2{ }^{3} \mathrm{H}-\mathrm{ATP}, 8-{ }^{3} \mathrm{H}$-cyclic 
AMP, $2-{ }^{3} \mathrm{H}-\mathrm{AMP}$, and $6-{ }^{3} \mathrm{H}$-thymidine from Radiochemical Centre (Amersham, England).

Ehrlich ascites tumor cells were maintained by weekly transfers in dd strain mice and were harvested for experiments on the 7th, 10th, and 14th day after inoculation into mice. Colchicine (30 $\mu \mathrm{g} /$ day) or mitomycin C (70 $\mu \mathrm{g} /$ day) was administered intraperitoneally for two successive days prior to cell harvest.

Cells harvested and washed were homogenized in solution containing $0.32 \mathrm{M}$ sucrose, $10 \mathrm{mM} \mathrm{MgCl}_{2}$, and $1 \mathrm{mM}$ dithiothreitol (pH 7.2) using a Polytron homogenizer. The homogenate was subjected to the following analyses. The activities of adenylate cyclase and 5'-nucleotidase were measured by the method of Salomon, Londos and Rodbell (11) with some modifications and Avruch and Wallach (1), respectively. Incorporation of ${ }^{3} \mathrm{H}$-thymidine into DNA was measured by the method of Chang, Morris and Looney (5). Protein and DNA were determined by the method of Lowry et al. (7) and Burton (4), respectively.

TABLE 1. EFFECT OF COLCHICINE ON THE ACTIVITIES OF ADENYLATE CYCLASE AND 5 '-NUCLEOTIDASE AND ON THYMIDINE INCORPORATION IN EHRLICH ASCITES TUMOR CELLS

\begin{tabular}{|c|c|c|c|c|}
\hline \multirow[t]{2}{*}{ Treatment } & \multicolumn{2}{|c|}{ Adenylate cyclase activity $a$} & \multirow{2}{*}{$\begin{array}{c}5^{\prime} \text {-Nucleotidase } \\
\text { activity } b\end{array}$} & \multirow{2}{*}{$\begin{array}{l}{ }^{3} \mathrm{H} \text {-thymidine } \\
\text { incorporation } c\end{array}$} \\
\hline & Basal & $\mathrm{NaF}$ & & \\
\hline Control & $1.6 \pm 0.3$ & $6.0 \pm 1.1$ & $27.8 \pm 5.8$ & $103.6 \pm 12.4$ \\
\hline Colchicine & $0.6 \pm 0.2$ & $2.4 \pm 0.5$ & $47.5 \pm 9.0$ & $69.0 \pm 24.0$ \\
\hline
\end{tabular}

a Activity is expressed as pmole cyclic AMP $/ \mathrm{min} / \mathrm{mg}$ protein.

$b$ Activity is expressed as pmole adenosine $/ \mathrm{min} / \mathrm{mg}$ protein.

$c$ Incorporation is expressed as pmole $/ \mathrm{mg} \mathrm{DNA} / 90 \mathrm{~min}$.

The figures represent mean \pm standard error of the mean of 5 specimens.

The activities of the membrane-associated enzymes, adenylate cyclase and 5'nucleotidase, were examined in tumor cells harvested on the 7th day after inoculation of cells into mice (after treatment with colchicine for 2 days on the 5 th and 6 th days of inoculation) to elucidate the possible involvement of the microtubular system in the function of the cell surface membrane. As shown in Table 1, the basal and NaFstimulated activities of adenylate cyclase were reduced to 38 and $40 \%$, respectively, of the untreated control level by treatment with colchicine. On the other hand, 5'nucleotidase activity was increased almost twice. Though the molecular mechanism of these changes is not clear, these results seem to indicate that the two membrane-bound enzymes are associated separately with the microtubular system, since the microtubules can be regarded as almost the sole object of colchicine action. To examine whether such colchicine effects could be observed in vitro on the activities of adenylate cyclase and 5'-nucleotidase, Ehrlich ascites tumor cells were incubated with $1.0 \mu \mathrm{M}$ colchicine at $37^{\circ} \mathrm{C}$ for $60 \mathrm{~min}$. The activities of the two enzymes responded similarly to in vivo changes but the in vitro colchicine effect was much weaker, possibly due to differences in duration of treatment.

Thus, this effect of colchicine on the two enzyme activities may be due to the inhibition of cell proliferation. The incorporation of ${ }^{3} \mathrm{H}$-thymidine into cell DNA was reduced by about $30 \%$ by in vivo treatment with colchicine, as shown in Table 1 . Results obtained by Rodan, Bourret and Cutler (10) on the same two enzyme activities in chick epiphyseal cartilage cells during maturation of cartilage are consistent with 
such an assumption. To examine this possibility, the relationship was studied between the growth condition of Ehrlich ascites tumor cells and the two enzyme activities at different stages after inoculation of cells, i.e., on the 7th, 10th, and 14th day. As shown in Fig. 1, the two enzyme activities decreased with the time after inoculation in a nearly parallel response, and the decrease was also parallel in reduction of ${ }^{3} \mathrm{H}$ thymidine incorporation into DNA. On the other hand, when tumor cell-bearing

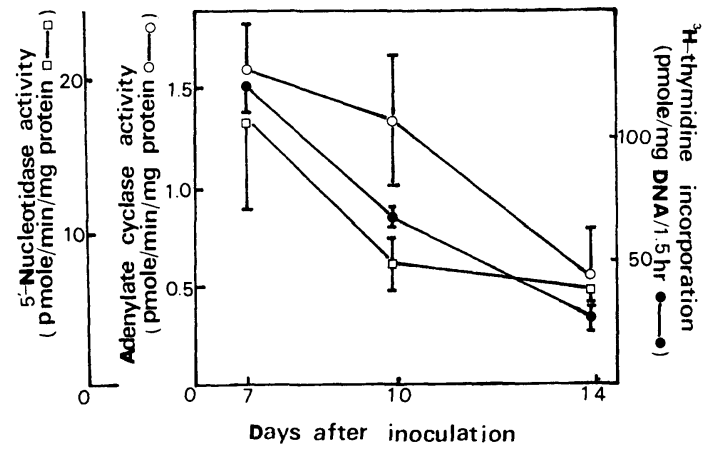

Fig. 1. Changes in enzyme activities and ${ }^{3} \mathrm{H}$-thymidine incorporation in Ehrlich ascites tumor cells with time after inoculation. Vertical bars indicate the standard errors of the mean.

mice were injected with mitomycin $\mathrm{C}$, the activity of NaF-stimulated adenylate cyclase was reduced to $64 \%$, which was much less than after colchicine treatment, whereas 5 '-nucleotidase activity was almost unchanged, in spite of almost complete inhibition (93\% inhibition) of ${ }^{3} \mathrm{H}$-thymidine incorporation into DNA (data not shown). These results seemed to indicate that the aforementioned changes in the two enzyme activities by colchicine treatment should not result simply from inhibition of cell proliferation.

As Oliver, Ukena and Berlin (8) reported that some cell surface membrane proteins, e.g. lectin binding sites, seemed to be regulated by a microtubular system, we are inclined to assume that this system is also involved in the control of membrane-associated enzymes. Recent findings of membrane tubulin (2) are of interest from such a viewpoint. However, since the colchicine treatment period was fairly long in the present study, the effect on host mice, which might affect the functioning of ascites tumor cells, should be considered as one problem to be clarified.

Acknowledgment. We are grateful to Dr. T. Takano for valuable discussion.

\section{REFERENCES}

1. Avruch, J. and D.F.H. Wallach. Preparation and properties of plasma membrane and endoplasmic reticulum fragments from isolated rat fat cells. Biochim. Biophys. Acta 233, 334 347,1971

2. Bhattacharyya, B. and J. Wolff. Polymerisation of membrane tubulin. Nature 264, 576577, 1976 
3. Bos, C.J. and P. Emmelot. Studies on plasma membrane. XXI. Inhibition of liver plasma membrane enzymes by tumor-promoting phorbol ester, mitotic inhibitors and cytochalasin $\mathbf{B}$. Chem. Biol. Interact. 8, 349-361, 1974

4. Burton, K. The relation between the synthesis of deoxyribonucleic acid and the synthesis of protein in the multiplication of bacteriophage T2. Biochem. J. 61, 473-483, 1955

5. Chang, L.O., H.P. Morris and W.B. LoONEY. Comparative incorporation of tritiated thymidine and cytidine into mitochondrial and nuclear DNA and RNA of two transplantable hepatomas (3924A and $\mathrm{H}-35 \mathrm{tc}_{2}$ ) and host liver. Cancer Res. 28, 2164-2167, 1968

6. Chen, K., J. Heller and E.S. Canellakis. Studies on the regulation of ornithine decarboxylase activity by the microtubules: The effect of colchicine and vinblastine. Biochem. Biophys. Res. Commun. 68, 401-408, 1976

7. Lowry, O.H., N.J. Rosebrough, A.L. FarR and R.J. Randall. Protein measurement with the Folin phenol reagent. J. Biol. Chem. 193, 265-275, 1951

8. Oliver, J.M., T.E. UkenA and R.D. Berlin. Effects of phagocytosis and colchicine on the distribution of lectin-binding sites on cell surface. Proc. Natl. Acad. Sci. USA 71, 394-398, 1974

9. Pohl, S.L., L. Birnbaumer and M. Rodbell. The glucagon-sensitive adenylate cyclase system in plasma membranes of rat liver. J. Biol. Chem. 246, 1849-1856, 1971

10. Rodan, G.A., L.A. Bourret and L.S. CutLer. Membrane changes during cartilage maturation. Increase in 5'-nucleotidase and decrease in adenosine inhibition of adenylate cyclase. J. Cell Biol. 72, 493-501, 1977

11. Salomon, Y., C. Londos and M. Rodbell. A highly sensitive adenylate cyclase assay. Anal. Biochem. 58, 541-548, 1974

12. Yahara I. and G.M. Edelman. The effects of concanavalin A on the mobility of lymphocyte surface receptors. Exp. Cell Res. 81, 143-155, 1973

(Received for publication, September 1, 1977) 